\title{
Discovery of a Series of 5-benzylidene-1, 3-thiazolidine-2, 4-dione-linked Chalcone Hybrids as a Novel Class of 5-Lipoxygenase (5-LO) Inhibitors
}

\author{
Vasudeva Rao Avupati ${ }^{1 *}$, Yuawa Rani ${ }^{2}$, Ashwinder Singh ${ }^{3}$ \\ 'Pharmaceutical Chemistry Division, School of Pharmacy, International Medical University, 126, Jln Jalil Perkasa 19, Bukit Jalil, Wilayah Persekutuan, Kuala Lumpur, \\ MALAYSIA. \\ 2Pharmacology Division, Faculty of Pharmacy, Asia Metropolitan University, G-8 Jalan Kemacahaya 11, Taman Kemacahaya, Cheras, Selangor, MALAYSIA. \\ 3Pharmaceutical Chemistry Division, Faculty of Pharmacy, Asia Metropolitan University, G-8 Jalan Kemacahaya 11, Taman Kemacahaya, Cheras, Selangor, MALAYSIA. \\ DOI: 10.5530/jyp.2018.10.53
}

In mammals, lipoxygenases (LOXs) are enzymes containing iron that are biological targets for essential fatty acids. These fatty acids are eicosanoids, derived from arachidonic acid, play important roles in implication and development of multifactorial inflammatory diseases. ${ }^{1}$ The 5-Lipoxygenase (5-LO) catalyses two-step reaction that is from arachidonic acid to leukotriene A4 (LTA4). In the first step, oxidation of arachidonic acid to an unstable reactive intermediate 5-hydroperoxyeicosatetraenoic acid (5-HPETE), followed by in the second step, dehydration of 5-HPETE to form LTA4. These reactions are initially leading to the biosynthesis of various classes of leukotrienes and plays a significant role in regulating leukotriene production. 5-LO has progressed its role through multiple mechanisms by its function, structure, cofactors, and the other regulatory mechanisms controlling its expression. ${ }^{2}$ Based on these functions, lipoxygenases were identified as potential drug-target associated with pathogenesis of inflammatory diseases. ${ }^{3}$ Zileuton is the only reversible direct inhibitor of 5-lipoxygenase that was marketed, due to its hepatotoxic effects the $300 \mathrm{mg}$ immediate release tablet was withdrawn from the U.S. market on February 12, 2008. ${ }^{4}$ Since there is an enormous demand for new 5-LO inhibitors, a series of 5-benzylidene-1,3-thiazolidine-2,4-dione-chalcone hybrids (1-24) which earlier synthesized and characterized in our study ${ }^{5}$ were subjected to High-throughput Screening (HTS) by 5-LO inhibition assay (UV-Kinetic method) as described by. ${ }^{6}$ The exploration of in vitro 5-LO inhibitory activity screening data (Figure 1) revealed that the compounds 20 and $\mathbf{1 8}$ were appeared to be demonstrated the most potent inhibitory activity, with $\mathrm{IC}_{50}$ values of $7.88 \pm 0.14$ and $11.77 \pm 0.21 \mu \mathrm{g} / \mathrm{mL}$. It is remarkable to note that the compounds 16, 17 and 12 also showed considerable inhibitory activity with $\mathrm{IC}_{50}$ values of $15.32 \pm 0.16,18.12 \pm 0.42$ and $18.12 \pm 0.32 \mu \mathrm{g} / \mathrm{mL}$ respectively. The other compounds such as 2-4, 9-11, 13-15, 21 and 24 showed modest level of activity at concentrations $\left(\mathrm{IC}_{50}\right)$ ranging from $22.18 \pm 0.11$ to $33.31 \pm 0.22 \mu \mathrm{g} / \mathrm{mL}$. The compounds $\mathbf{1}$, 5-8, 19, 22 and 23 showed relatively less activity with $\mathrm{IC}_{50}$ values ranging from $35.11 \pm 0.23$ to $46.22 \pm 0.12 \mu \mathrm{g} / \mathrm{mL}$ in comparison with the standard (abietic acid (LI01020), $\mathrm{IC}_{50}: 4.34 \pm 0.37 \mu \mathrm{g} / \mathrm{mL}$ ).

A closer investigation at the Structure-Activity Relationship (SAR) of these compounds openly showed the inherent mechanism of 5-LO inhibitory potential related with the basic scaffold comprising of 1,3-thiazolidine-2,4-dione and $\alpha, \beta$ - unsaturated ketone moieties as observed in case of the compound $\mathbf{1}$ which is an unsubstituted compound, with $\mathrm{IC}_{50}$ value of $38.66 \pm 0.25 \mu \mathrm{g} / \mathrm{mL}$, which in some compounds, improved by the influence of some functional group substituents and decreased by some other functional group substituents. For instance, the compounds
$18\left(p-\mathrm{F}, \mathrm{IC}_{50}: 11.77 \pm 0.21 \mu \mathrm{g} / \mathrm{mL}\right)>\mathbf{1 6}\left(p-\mathrm{Cl}, \mathrm{IC}_{50}: 15.32 \pm 0.16 \mu \mathrm{g} / \mathrm{mL}\right)$ $>17\left(m-\mathrm{F}_{1} \mathrm{IC}_{50}: 18.12 \pm 0.42 \mu \mathrm{g} / \mathrm{mL}\right)>\mathbf{1 5}\left(m-\mathrm{Cl}, \mathrm{IC}_{50}: 24.81 \pm 0.51 \mu \mathrm{g} / \mathrm{mL}\right)$ having halogen substituents either at para or meta positions relatively enhanced the activity. A decrease in the activity was seen when the substituted phenyl ring was changed by a naphthalene ring, as observed in the case of compound 23 with $\mathrm{IC}_{50}$ value $44.38 \pm 0.13 \mu \mathrm{g} / \mathrm{mL}$. The existence of a 3-pyridyl ring in compound 22 in the place of substituted phenyl ring of $\alpha, \beta$ - unsaturated carbonyl moiety improved the activity compared to the compound that possessing naphthalene ring as substituent, but less than that of the compound having phenyl ring substituted with functional groups. Likewise, it is also remarkable to understand that the presence of 2-pyridyl ring in the place of substituted phenyl ring contributed to an increase in activity compared to the one possessing pyridin-3-yl ring, respectively as observed in the case of compounds 21 and 22 with $\mathrm{IC}_{50}$ values $33.31 \pm 0.22$ and $41.22 \pm 0.49 \mu \mathrm{g} / \mathrm{mL}$, respectively. It was observed that the replacement of substituted phenyl ring with thiophene $\left(20, \mathrm{IC}_{50}: 7.88 \pm 0.14 \mu \mathrm{g} / \mathrm{mL}\right)$ and fluorene $\left(\mathbf{2 4}, \mathrm{IC}_{50}: 29.13\right.$ $\pm 0.23 \mu \mathrm{g} / \mathrm{mL}$ ) rings improved 5-LO inhibitory activity. Conversely, it was revealed that various aromatic/heteroaromatic rings substituted at position 3 of $\alpha, \beta$ - unsaturated carbonyl system followed its activity order as thiophen-2-yl $>$ fluoren-2-yl $>$ pyridin-2-yl $>$ phenyl $>$ pyridin3 -yl $>$ naphthalen-2-yl moieties, respectively. It is also reported that the compounds substituted with electron releasing groups were found to be biologically more significant and the order of inhibitory potential was $\left(12\left(4-\mathrm{NH}_{2}, \mathrm{IC}_{50}: 18.12 \pm 0.32 \mu \mathrm{g} / \mathrm{mL}\right)>4\left(4-\mathrm{OCH}_{3}, \mathrm{IC}_{50}: 22.18 \pm 0.11\right.\right.$ $\mu \mathrm{g} / \mathrm{mL})>3\left(3-\mathrm{OCH}_{3}, \mathrm{IC}_{50}: 23.11 \pm 0.32 \pm 0.23 \mu \mathrm{g} / \mathrm{mL}\right)>\mathbf{2}\left(4-\mathrm{CH}_{3}, \mathrm{IC}_{50}\right.$ : $\left.25.24 \pm 0.45 \mu \mathrm{g} / \mathrm{mL})>11\left(3-\mathrm{NH}_{2}, \mathrm{IC}_{50}: 29.41 \pm 0.27 \mu \mathrm{g} / \mathrm{mL}\right)\right)$, respectively. It is essential that relatively less activity was seen when the hydroxyl groups are substituted at different positions on the phenyl ring as observed in the case of compounds 5-8 and the order of activity was 5 $\left(2-\mathrm{OH}, \mathrm{IC}_{50}: 35.13 \pm 0.45 \mu \mathrm{g} / \mathrm{mL}\right)>6\left(4-\mathrm{OH}, \mathrm{IC}_{50}: 39.24 \pm 0.34 \mu \mathrm{g} / \mathrm{mL}\right)>$ $8\left(2,4-\mathrm{diOH}, \mathrm{IC}_{50}: 44.18 \pm 0.53 \mu \mathrm{g} / \mathrm{mL}\right)>7\left(2,5-\mathrm{diOH}, \mathrm{IC}_{50}: 46.22 \pm 0.12\right.$ $\mu \mathrm{g} / \mathrm{mL})$, respectively. The compounds $10\left(\mathrm{IC}_{50}: 22.18 \pm 0.17 \mu \mathrm{g} / \mathrm{mL}\right)$ and $9\left(\mathrm{IC}_{50}: 26.31 \pm 0.52 \mu \mathrm{g} / \mathrm{mL}\right.$ ) having substituted with the methyl group on the phenyl ring at position 5 along with the hydroxyl group substitution at $6(10)$ and $2(9)$ positions, respectively showed enhanced level of 5 -LO inhibitory potential when compared with that of the compounds (5-8) possessing only hydroxyl group substitution. It is unexpected that improved level of activity was observed when the nitro group hosted on to the phenyl ring of $\alpha, \beta$ - unsaturated ketone system at 3 and 4 positions as observed in case of compounds $\mathbf{1 4}$ and $\mathbf{1 3}$ with $\mathrm{IC}_{50}$ values $24.28 \pm 0.13$ and $33.66 \pm 0.6 \mu \mathrm{g} / \mathrm{mL}$, respectively. The compound $19\left(\mathrm{IC}_{50}: 35.11 \pm 0.23\right.$ $\mu \mathrm{g} / \mathrm{mL}$ ) having substituted with dibenzyloxy group on the phenyl ring at 


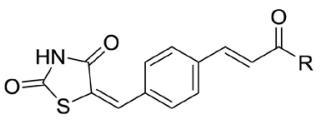

$(1-24)$

\begin{tabular}{llllll}
\hline Compound & $\mathrm{R}$ & $\begin{array}{l}\mathrm{IC}_{50}(\mu \mathrm{g} / \mathrm{mL}) \\
(\mathrm{mean} \pm \mathrm{SEM})\end{array}$ & Compound & $\mathrm{R}$ & $\begin{array}{l}\mathrm{IC}_{50}(\mu \mathrm{g} / \mathrm{mL}) \\
(\mathrm{mean} \pm \mathrm{SEM})\end{array}$ \\
\hline 1 & $\mathrm{C}_{6} \mathrm{H}_{5}$ & $38.66 \pm 0.25$ & 14 & $4-\mathrm{NO}_{2} \mathrm{C}_{6} \mathrm{H}_{4}$ & $24.28 \pm 0.13$ \\
2 & $4-\mathrm{MeC}_{6} \mathrm{H}_{4}$ & $25.24 \pm 0.45$ & 15 & $3-\mathrm{ClC}_{6} \mathrm{H}_{4}$ & $24.81 \pm 0.51$ \\
3 & $3-\mathrm{OMeC}_{6} \mathrm{H}_{4}$ & $23.11 \pm 0.32$ & 16 & $4-\mathrm{ClC}_{6} \mathrm{H}_{4}$ & $15.32 \pm 0.16$ \\
4 & $4-\mathrm{OMeC}_{6} \mathrm{H}_{4}$ & $22.18 \pm 0.11$ & 17 & $3-\mathrm{FC}_{6} \mathrm{H}_{4}$ & $18.12 \pm 0.42$ \\
5 & $2-\mathrm{OHC}_{6} \mathrm{H}_{4}$ & $35.13 \pm 0.45$ & 18 & $4-\mathrm{FC}_{6} \mathrm{H}_{4}$ & $11.77 \pm 0.21$ \\
6 & $4-\mathrm{OHC}_{6} \mathrm{H}_{4}$ & $39.24 \pm 0.34$ & 19 & $3,5-d i C_{7} \mathrm{H}_{7} \mathrm{OC}_{6} \mathrm{H}_{3}$ & $35.11 \pm 0.23$ \\
7 & $2,4-\mathrm{diOHC}_{6} \mathrm{H}_{3}$ & $46.22 \pm 0.12$ & 20 & Thiophen-2-yl & $7.88 \pm 0.14$ \\
8 & $2,5-\mathrm{diOHC}_{6} \mathrm{H}_{3}$ & $44.18 \pm 0.53$ & 21 & Pyridin-2-yl & $33.31 \pm 0.22$ \\
9 & $2-\mathrm{OH}, 5-\mathrm{MeC}_{6} \mathrm{H}_{3}$ & $26.31 \pm 0.52$ & 22 & Pyridin-3-yl & $41.22 \pm 0.49$ \\
10 & $6-\mathrm{OH}_{5}-\mathrm{MeC}_{6} \mathrm{H}_{3}$ & $22.18 \pm 0.17$ & 23 & Naphthalen-2-yl & $44.38 \pm 0.13$ \\
11 & $3-\mathrm{NH}_{2} \mathrm{C}_{6} \mathrm{H}_{4}$ & $29.41 \pm 0.27$ & 24 & Fluoren-2-yl & $29.13 \pm 0.23$ \\
12 & $4-\mathrm{NH}_{2} \mathrm{C}_{6} \mathrm{H}_{4}$ & $18.12 \pm 0.32$ & Abietic acid & - & $4.34 \pm 0.37$ \\
13 & $3-\mathrm{NO}_{2} \mathrm{C}_{6} \mathrm{H}_{4}$ & $33.66 \pm 0.61$ & (LI01020) & & \\
\hline
\end{tabular}

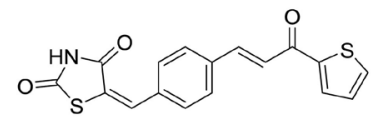

Compound 20: $\mathrm{IC}_{50}(7.88 \pm 0.14 \mu \mathrm{g} / \mathrm{mL})$

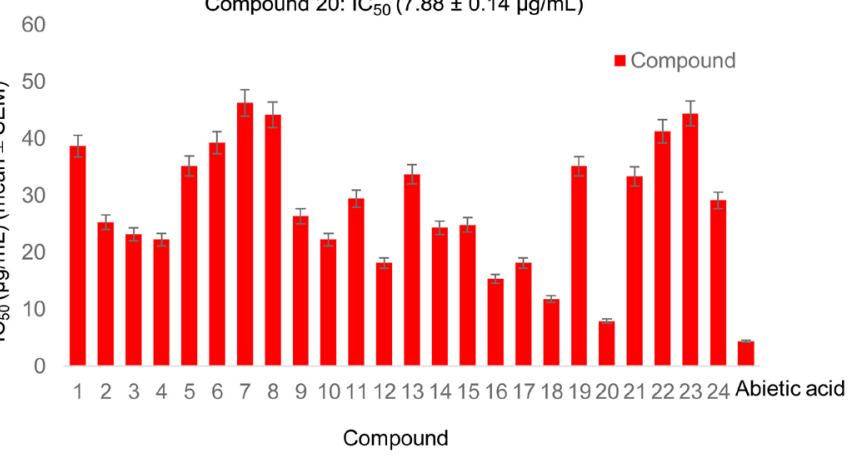

Figure 1: 5-LO inhibitory activity data of 5-benzylidene-1,3-thiazolidine-2,4-dione-chalcone hybrids 1-24.

positions 3 and 5 displayed lower level of 5-LO inhibitory activity. In summary, the SAR revealed the positive contribution of $\alpha, \beta$-unsaturated ketone and 5-benzylidene-1, 3-thiazolidine-2, 4-dione moieties towards the observed activity. The results indicated that further development of thiophene ring substitution could be of biological interest.

\section{ACKNOWLEDGEMENT}

One of the authors Vasudeva Rao Avupati is thankful to the Dean, Faculty of Pharmacy and to the Vice-chancellor, Asia Metropolitan University, Malaysia for providing research lab space and instrumentation facilities to carry out the research work.

\section{CONFLICT OF INTEREST}

The authors declare no conflict of interest.

\section{REFERENCES}

1. Pontiki E, Hadjipavlou-Litina D. Lipoxygenases (LOs): an heterogenous family of lipid peroxidizing enzymes implicated in cell differentiation, inflammation, asthma, carcinogenesis, atherogenesis-an interesting target for the development of promising drugs. Curr Enzym Inhib. 2005;1(3):309-27.

2. Radmark O, Werz O, Steinhilber D, Samuelsson B. 5-Lipoxygenase: regulation of expression and enzyme activity. Trends Biochem Sci. 2007;32(7):332-41.

3. Kaur G, Silakari O. Multiple target-centric strategy to tame inflammation. Future Med Chem. 2017;9(12):1361-76.

4. Patel N, Pandya K, Gajjar A. An Overview of Different Analytical Techniques for Leukotriene Antagonists in Different Matrices. Curr Phar Anal. 2016;12(4):275-95.

5. Avupati VR, Yejella RP, Akula A, Guntuku GS, Doddi BR, Vutla VR, et al. Synthesis, characterization and biological evaluation of some novel 2, 4-thiazolidinediones as potential cytotoxic, antimicrobial and antihyperglycemic agents. Bioorganic Med Chem Lett. 2012;22(20):6442-50.

6. Sircar JC, Schwender CF, Carethers ME. Inhibition of soybean lipoxygenase by sulfasalazine and 5-aminosalicylic acid: a possible mode of action in ulcerative colitis. Biochem Pharmacol. 1983;32(1):170-2. 